\title{
SISTEM E-LIBRARY BERBASIS WEB MOBILE PADA DINAS PERPUSTAKAAN DAN KEARSIPAN (STUDI KASUS : DINAS PERPUSTAKAAN DAN KEARSIPAN PROVINSI LAMPUNG)
}

\author{
Resi Wulansari ${ }^{1}$, Arman Suryadi Karim ${ }^{2}$ \\ ${ }^{1,2}$ Institut Informatika dan Bisnis Darmajaya (IIB) Darmajaya \\ ${ }^{1}$ resiwulansariechy@gmail.com
}

\begin{abstract}
A library with a digital concept (Digital Library) is one solution to overcome the obstacles of the conventional library concept. Thus, it can be accessed by users without restrictions on place and time. By utilizing information technology, it can increase interest in reading and add people's knowledge. In order to develop and maintain the learning process, innovation and renewal will continue to improve. The mobile web-based on e-Library system in the Department for Libraries and Archives of Lampung was designed using the waterfall model method. This system used PHP and $M y S Q L$ programming languages as its database. As a result of this study, this e-library system was able to assist the public in finding information on books, journals, e-books, video tutorials, and lessons. So that this system is able to increase people's interest in reading and add to people's knowledge.
\end{abstract}

Keywords: E-Library; Digital Library; Waterfall

\begin{abstract}
Abstrak
Perpustakaan dengan konsep digital (Digital Library) merupakan salah satu solusi untuk mengatasi kendala dari konsep perpustakaan tradisional. Sehingga mampu diakses oleh pengguna tanpa batasan tempat dan waktu. Dengan memanfaatkan teknologi infromasi dapat menambah minat baca dan menambah wawasan pengetahuan masyarakat. Dalam rangka mengembangkan dan menjaga proses pembelajaran, inovasi dan pembaharuan akan terus dikembangkan. Sistem e-Library berbasis web mobile yang ada pada Dinas Perpustakaan dan Kearsipan Provinsi Lampung ini dirancang dengan menggunakan metode model waterfall. Sistem ini dibangun dengan menggunakan bahasa pemrograman $P H P$ dan MySQL sebagai database nya. Sistem e-Library ini dapat membantu masyarakat dalam mencari informasi buku, jurnal, $e$-book, serta tersedia video tutorial dan pembelajaran. Sehingga sistem ini mampu meningkatkan minat baca masyarakat dan menambah wawasan pengetahuan masyarakat.
\end{abstract}

Kata kunci: e-library; digital library; waterfall.

\section{PENDAHULUAN}

Sistem pengolahan data elektronik dapat mengakses kebutuhan terhadap penyajian informasi yang cepat saji dan berwawasan. Perpustakaan merupakan tempat yang bisa dimanfaatkan untuk mencari beberapa referensi buku untuk dipinjam, ataupun hanya dibaca di sana. Dengan adanya pemanfaatan teknologi informasi seperti internet maka kebutuhan akan penyampaian dan pencarian informasi dapat dilakukan dengan cepat, sebab internet merupakan jaringan yang sangat luas dan merupakan sarana yang efektif dan efisien untuk penyampaian dan pencarian informasi. Sesuai dengan visi dan misi Pemerintah Daerah Provinsi Lampung, Dinas Perpustakaan dan Kearsipan Provinsi Lampung mempunyai bidang yang mendukung pengembangan pendidikan, iptek dan inovasi, dan budaya masyarakat. Hal ini sejalan dengan tujuan perpustakaan sebagaimana diamanatkan dalam Undang - Undang Nomor 43 Tahun 2007 tentang Perpustakaan. Pada Pasal 4 dinyatakan bahwa "Perpustakaan bertujuan memberikan layanan kepada 
pemustaka, meningkatkan kegemaran membaca serta memperluas wawasan dan pengetahuan untuk mencerdaskan kehidupan bangsa”.

Sementara Indonesia yang merupakan salah satu negara berkembang di Asia, memiliki minat baca yang cukup rendah. Berdasarkan studi dari "MostLittered Nation In The World" yang dilakukan oleh Central Connecticut State University pada Maret 2016, Indonesia dinyatakan menduduki peringkat ke 60 dari 61 negara soal minat baca (Kompas.com). Sebagai solusi dari permasalahan tersebut, pemerintah menggalakkan pembangunan perpustakaan dan taman baca sebagai salah satu fasilitas untuk meningkatkan minat baca masyarakat. Namun, pengembangan perpustakaan dengan konsep tradisional yang diterapkan pemerintah memiliki berbagai kendala dari segi biaya yang cukup besar, jangkauan penyebaran informasi yang terbatas dan sumber daya yang tidak memadai.

Perpustakaan dengan konsep digital (Digital Library) merupakan salah satu solusi untuk mengatasi kendala dari konsep perpustakaan tradisional. Perpustakaan digital (Digital Library) atau disebut juga sebagai perpustakaan elektronik (e-library) diperkenalkan dengan kelebihannya menyediakan koleksi dalam bentuk elektronik yang mampu diakses oleh pengguna tanpa batasan tempat dan waktu dengan menggunakan media elektronik seperti komputer, laptop maupun gadget yang terhubung dengan jaringan internet.

Hingga 2019, jumlah pemustaka di Dinas Perpustakaan Provinsi Lampung berjumlah 342.518 orang, peminjam berjumlah 79.085 orang. Jumlah buku dibaca 231.018 eksemplar dan buku dipinjam 92.952 eksemplar. Melihat data tersebut, penulis merasa perlu membuatkan sistem yang mempermudah akses membaca buku dan peminjaman buku secara online.

Tujuannya selain meningkatkan minat baca masyarakat juga meningkatkan jumlah peminjam, baik yang datang ke perpustakaan secara langsung maupun peminjam secara online.

\section{TINJAUAN PUSTAKA}

\subsection{Pengertian Perpustakaan}

Menurut Sulistyo Basuki, perpustakaan adalah ruangan, bagian dari sebuah gedung ataupun gedung itu sendiri yang digunakan untuk menyimpan buku atau terbitan lainnya yang biasanya disimpan menurut tata susunan tertentu untuk digunakan sebagai bahan bacaan bukan untuk dijual (Hartono, 2016:26).

\subsection{Pengertian E-Librarry}

Menurut Basuki Rahmad (2013), e-Library merupakan suatu kumpulan/koleksi artikel-artikel dan laporan yang tersedia untuk bacaan online atau download. E-Library mengarah pada inisiatif pembelajaran integratif yang bisa diterapkan pada perpustakaan, sehingga pengunjung perpustakaan bisa mendapatkan referensi yang tepat dalam mencari suatu informasi.

\subsection{Sistem E-Library Berbasis Web Mobile}

Sistem perpustakaan digital merupakan suatu metode instruksional penyampaian referensi buku untuk mempermudah pencarian buku dan referensi buku tanpa dibatasi oleh device, jarak, waktu, dan tempat serta kesempatan untuk melihat referensi-referensi buku bagi semua golongan yang memenuhi persyaratan tertentu. Proses e-Library yang terjadi dapat dijembatani dengan suatu media untuk melakukan aktivitas pencarian referensi-referensi buku. Oleh karenanya batasan yang dihadapi dapat dikurangi atau bahkan dihilangkan. Didalam sistem e-Library di Dinas Perpustakaan dan Kearispan Provinsi Lampung ini terdapat beberapa pelaku yang memungkinkan sistem ini 
untuk digunakan. Pelaku-pelaku tersebut adalah Akademis, administrator, dan masyarakat umum. Akademisi merupakan pihak-pihak yang melakukan pencarian informasi buku serta memanfaatkan sistem dalam lingkup civitas akademia

\subsection{Pengertian Sistem}

Pengertian sistem menurut Romney dan Steinbart (2015:3), sistem adalah rangkaian dari dua atau lebih komponen-komponen yang saling berhubungan dan berinteraksi untuk mencapai suatu tujuan. Sebagian besar sistem terdiri dari sub sistem yang lebih kecil yang mendukung sistem yang lebih besar. Menurut McLeod yang dikutip oleh Rini Asmara (2016) adalah sebagai berikut: “ A system is a group of elements that are integrated with the common propose of achieving an abjective”. Sistem adalah sekelompok elemen yang terintegrasi dengan maksud yang sama untuk mencapai suatu tujuan.

\subsection{Pengertian Informasi}

Secara etimologi, informasi berasal dari bahasa Perancis kuno yaitu Informaction yang daimbil dari bahasa latin Informationem yang berarti "garis besar, konsep, ide. Menurut Gordon B Davis yang dikutip oleh Rini Asmara (2016) informasi adalah data yang telah diolah menjadi suatu bentuk yang penting bagi si penerima dan mempunyai nilai nyata yang dapat dirasakan dalam keputusan-keputusan yang sekarang atau keputusan-keputusan yang akan datang.

\subsection{Pengertian Sistem Informasi}

Menurut Loudon yang dikutip oleh Rini Asmara (2016), an information system can be defined technically as a set of interrelated components that collect (or retrieve), prosess, store and distribute information to suport decision making and control in an organization. Sistem informasi adalah kumpulan komponen yang saling berhubungan dalam mengumpulkan, memproses, menyimpan, menyediakan, dan mendistribusikan infromasi untuk mendukung pengmabilan keputusan dan pengendalian didalam organisasi.

Pada umumnya sistem informasi merupakan gabungan dari manusia, perangkat keras, perangkat lunak, jaringan, dan sumber data yang dikumpulkan dan diolah sedemikian rupa lalu disebarkan didalam sebuah organisasi atau perusahaan sehingga dapat mendukung perusahaan dan berbagai macam pelaku usaha dalam menjalankan kegiatan usaha ataupun organisasi.

\section{METODE PENELITIAN}

Pengumpulan data dalam penelitian ini menggunakan beberapa metode yaitu: Wawancara (Interview). Wawancara telah diakui sebagai teknik pengumpulan data/fakta yang penting dan banyak dilakukan dalam pengembangan sistem informasi. Wawancara dilakukan dengan cara menanyakan secara langsung kepada pihak-pihak yang berkaitan dengan bagiannya untuk memperoleh informasi Dinas Perpustakaan dan Kearsipan Provinsi Lampung,Dokumentasi (Documentation) Untuk mengumpulkan data yang bersumber dari arsip dan dokumen, baik yang ada di dalam Dinas Perpustakaan dan Kearsipan Provinsi Lampung ataupun yang di luar Dinas Perpustakaan dan Kearsipan Provinsi Lampung yang ada hubungannya dengan masalah yang dibahas, Tinjauan Pustaka (Library Research),Mempelajari kumpulan buku-buku yang dilakukan dengan cara membaca literatur-literatur dan tata bahasa 
yang baik yang ada yang terkait dengan data yang dibutuhkan, sehingga dapat menunjang proses penelitian seperti jurnal dan buku Pressman 2012 dan Rosa 2013. Model SDLC air terjun (waterfall) sering juga disebut model sekuensi linier (sequential linier) atau alur hidup klasik (classic life cycle). Model air terjun menyediakan pendekatan alur hidup perangkat lunak secara sekuensial atau terurut dimulai dari analisis, desain, pengodean, pengujian, dan tahap pendukung (Support). (Rosa, 2019) seperti Gambar 1. berikut ini.

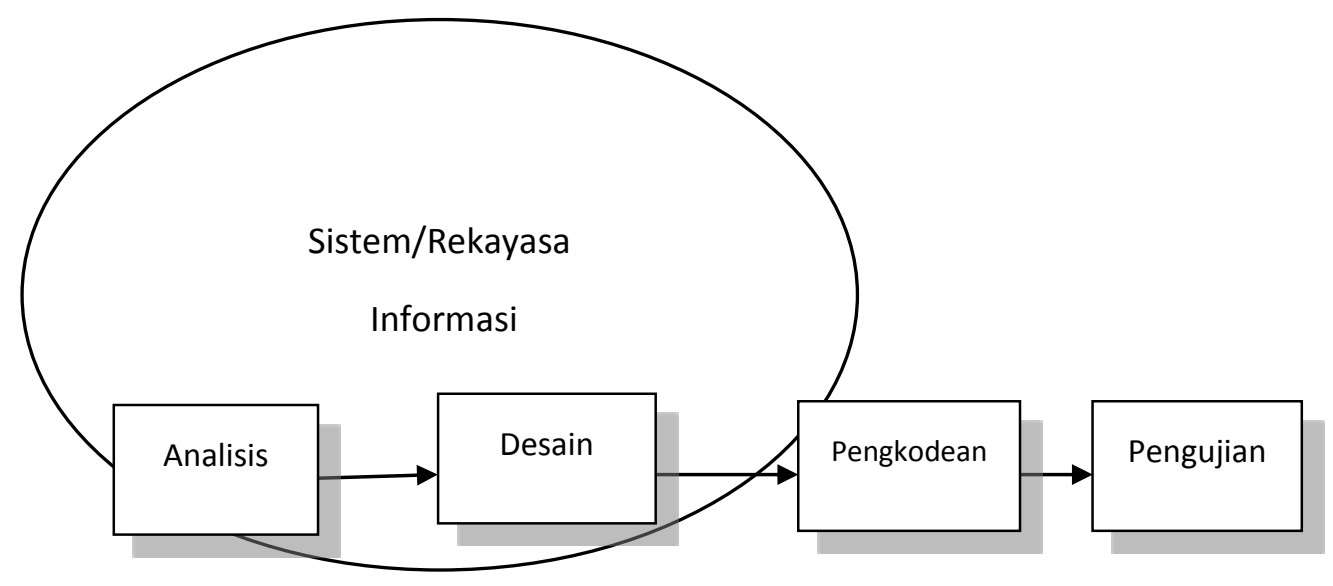

Gambar 1. Metode Waterfall

\section{HASIL DAN PEMBAHASAN}

a. Tampilan Home

Tampilan ini merupakan tampilan utama setelah user masuk ke dalam website.

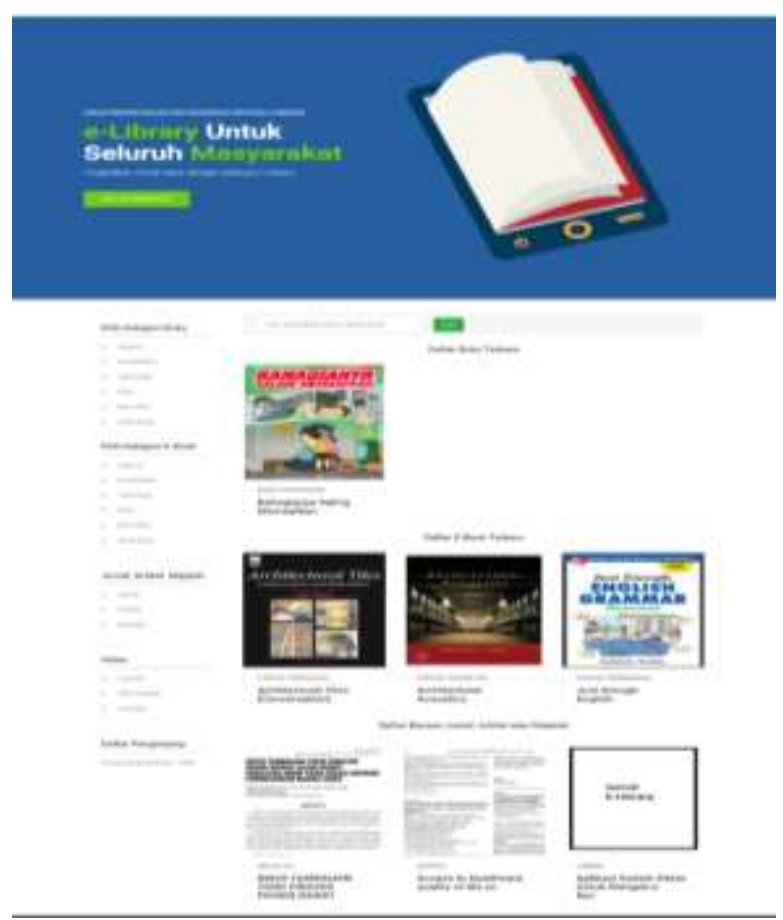

Gambar 2. Tampilan Home 


\section{b. Tampilan List Buku}

Merupakan tampilan yang menunjukkan data buku dalam bentuk Kategori buku.

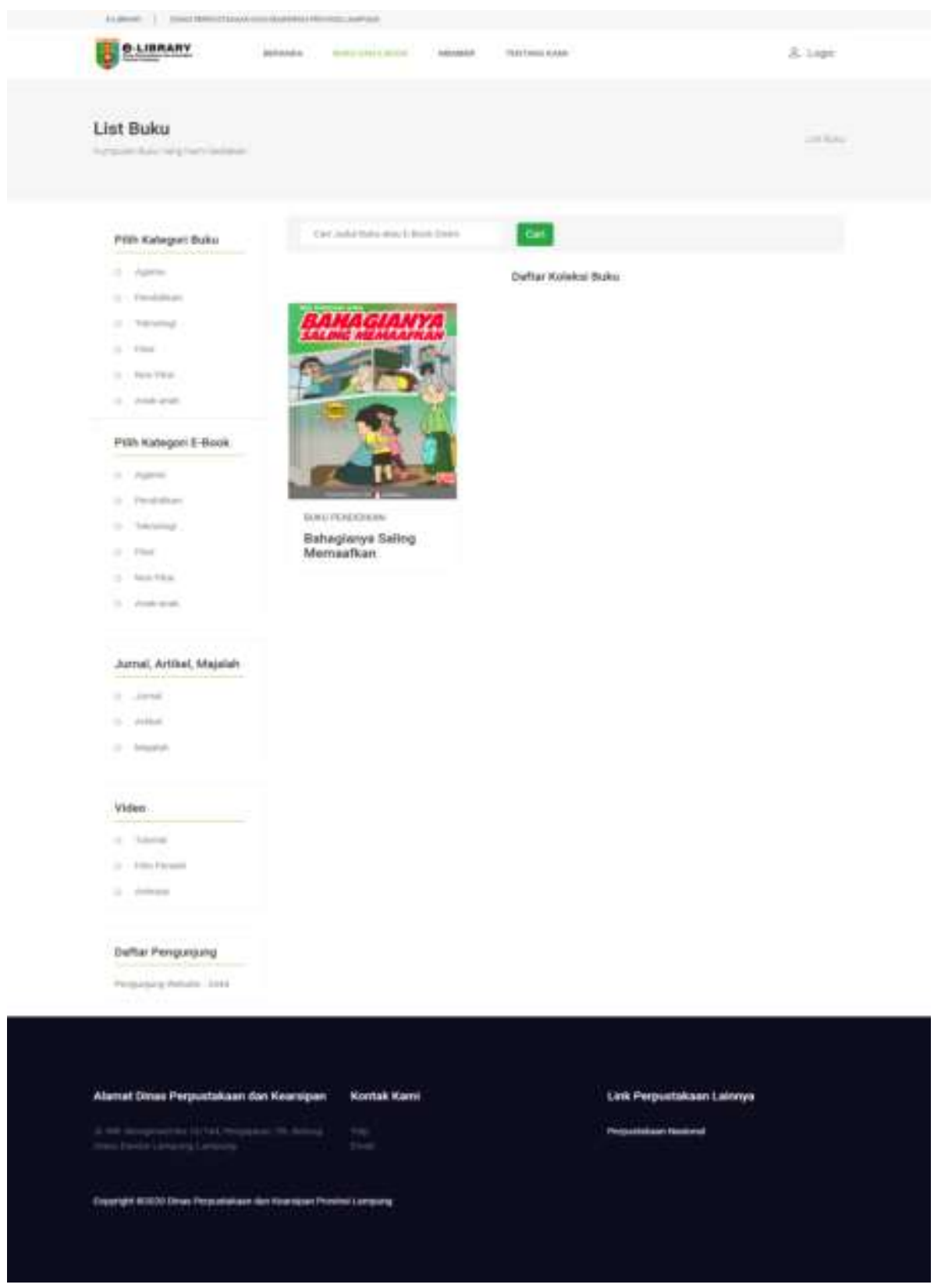

Gambar 2. Tampilan List Buku 
c. Tampilan List E-Book

Merupakan tampilan yang menunjukkan data buku dalam bentuk Kategori buku.

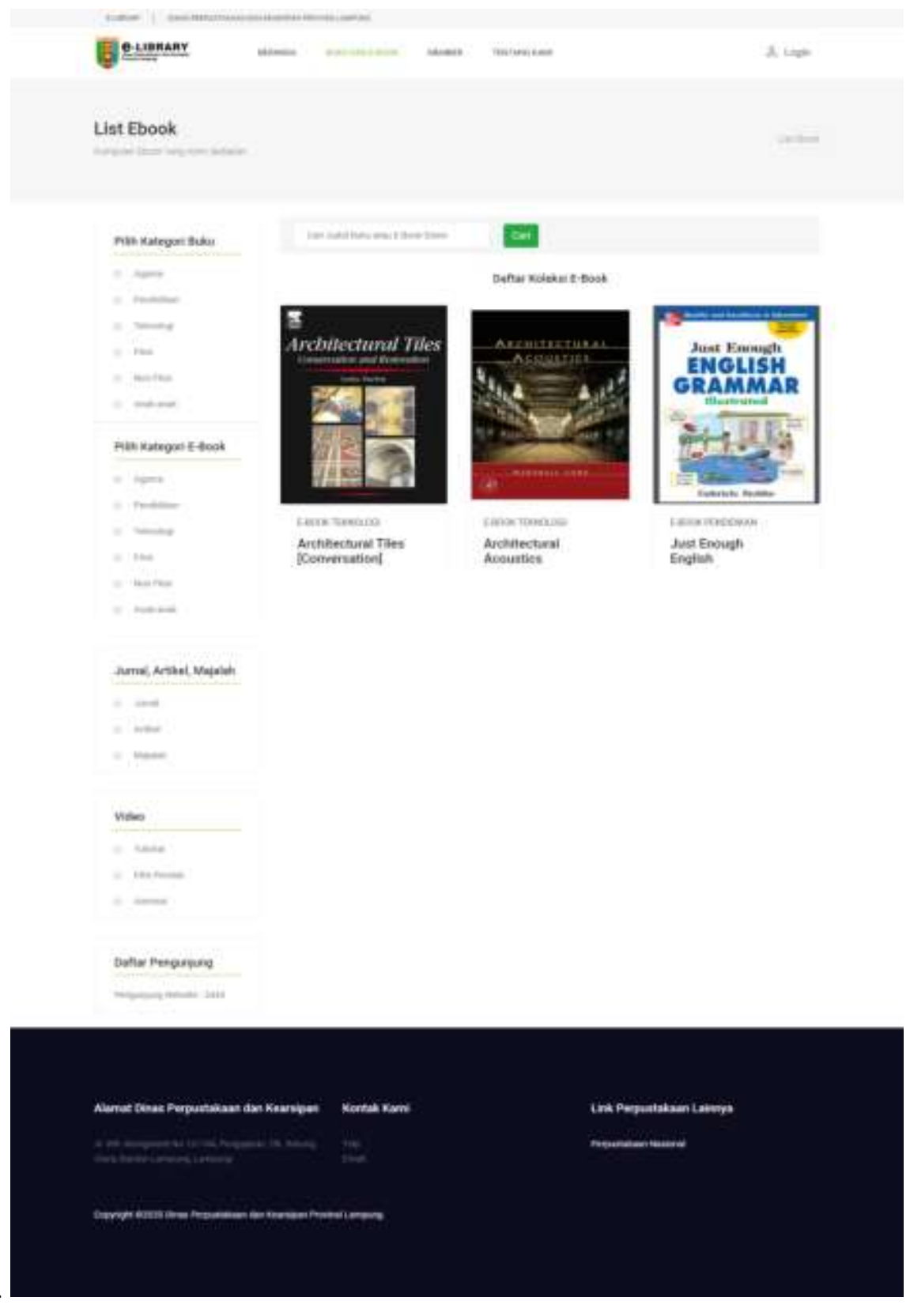

Gambar 3. Tampilan List E-book 
d. Tampilan Pinjaman Buku

Merupakan tampilan yang menampilkan tampilan pinjaman buku

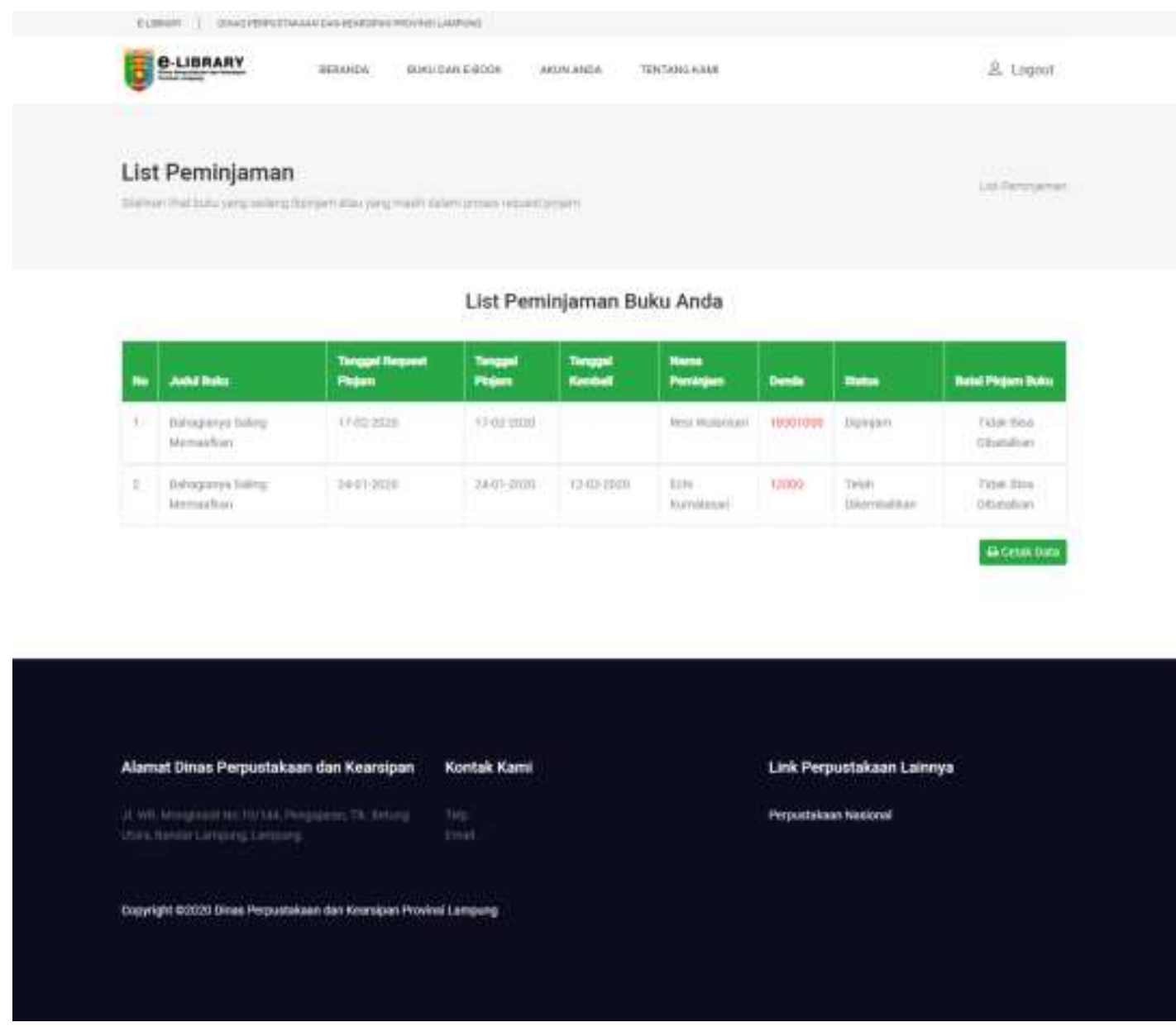

Gambar 4. Tampilan Pinjaman Buku 
e. Tampilan Data Buku

Menampilkan data buku yang ada dan berfungsi untuk menambah dan menghapus data buku.

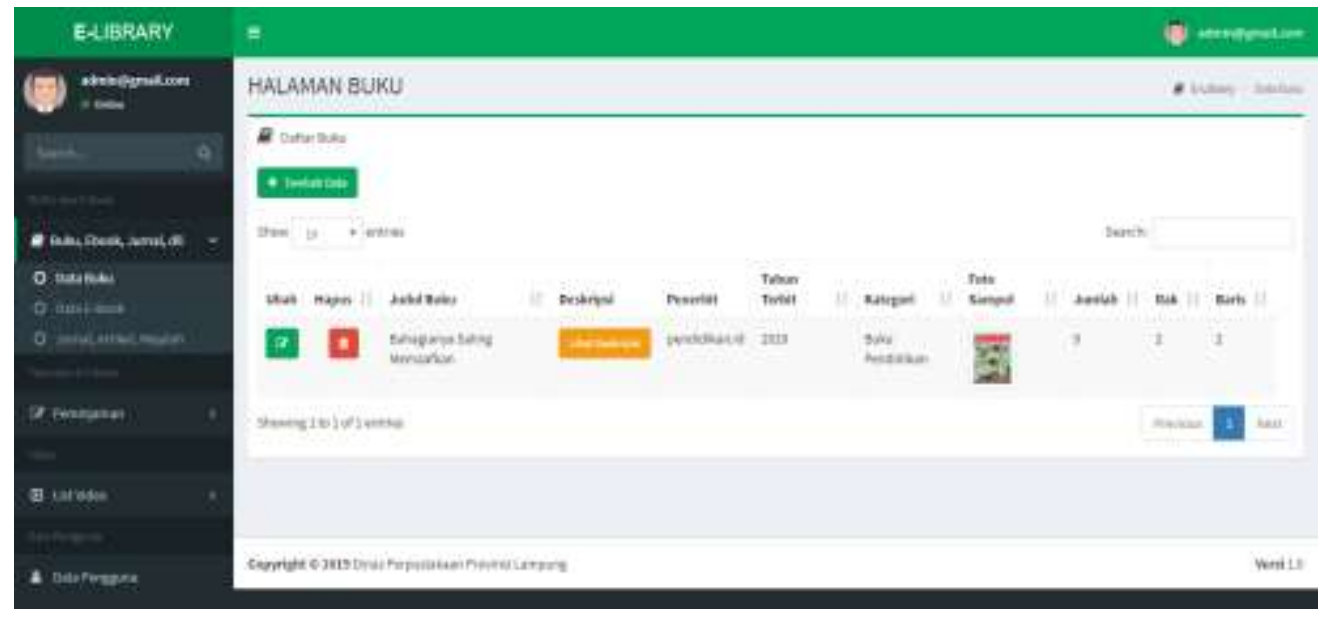

Gambar 5. Tampilan Data Buku

f. Tampilan Data E-Book

Menampilkan data E-book yang ada dan berfungsi untuk menambah dan menghapus.

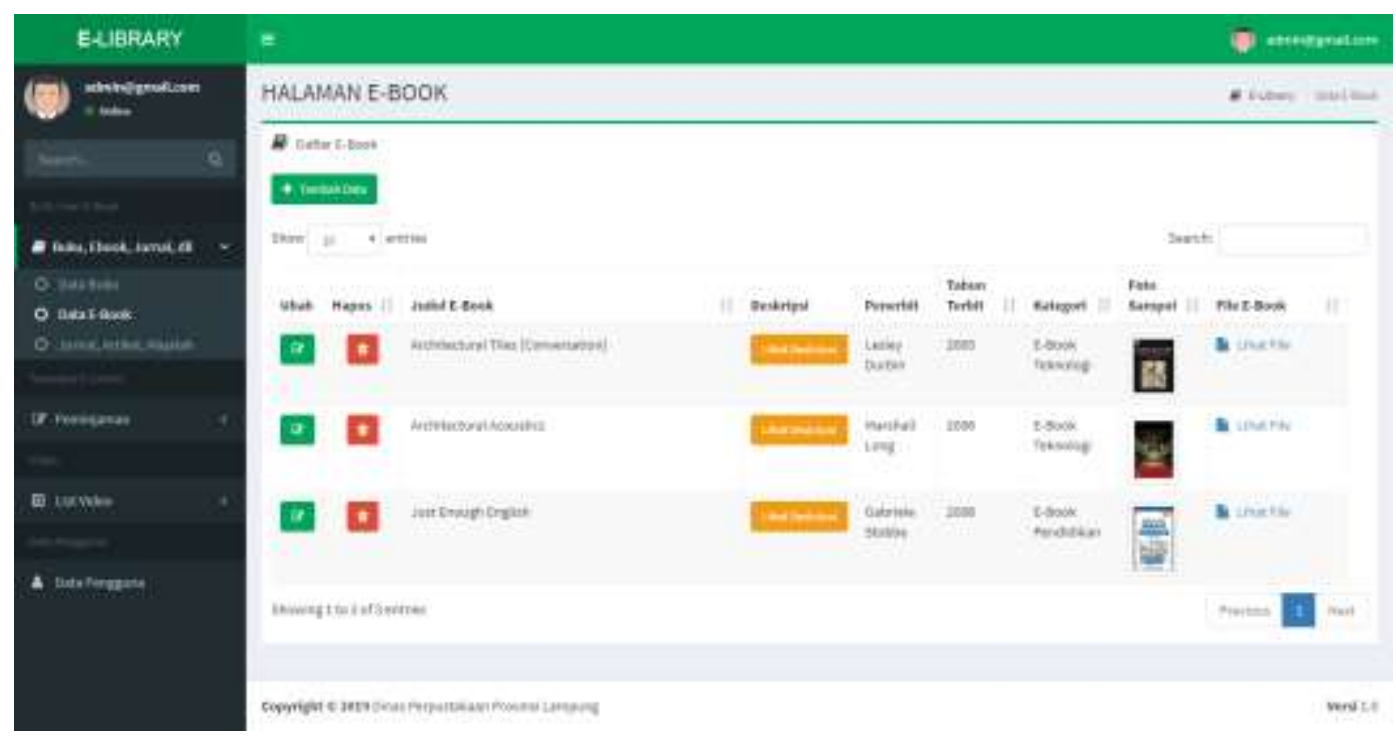

Gambar 6. Tampilan Data Ebook

g. Tampilan Data Jurnal

Menampilkan data Jurnal yang ada dan berfungsi untuk menambah dan menghapus data jurnal 


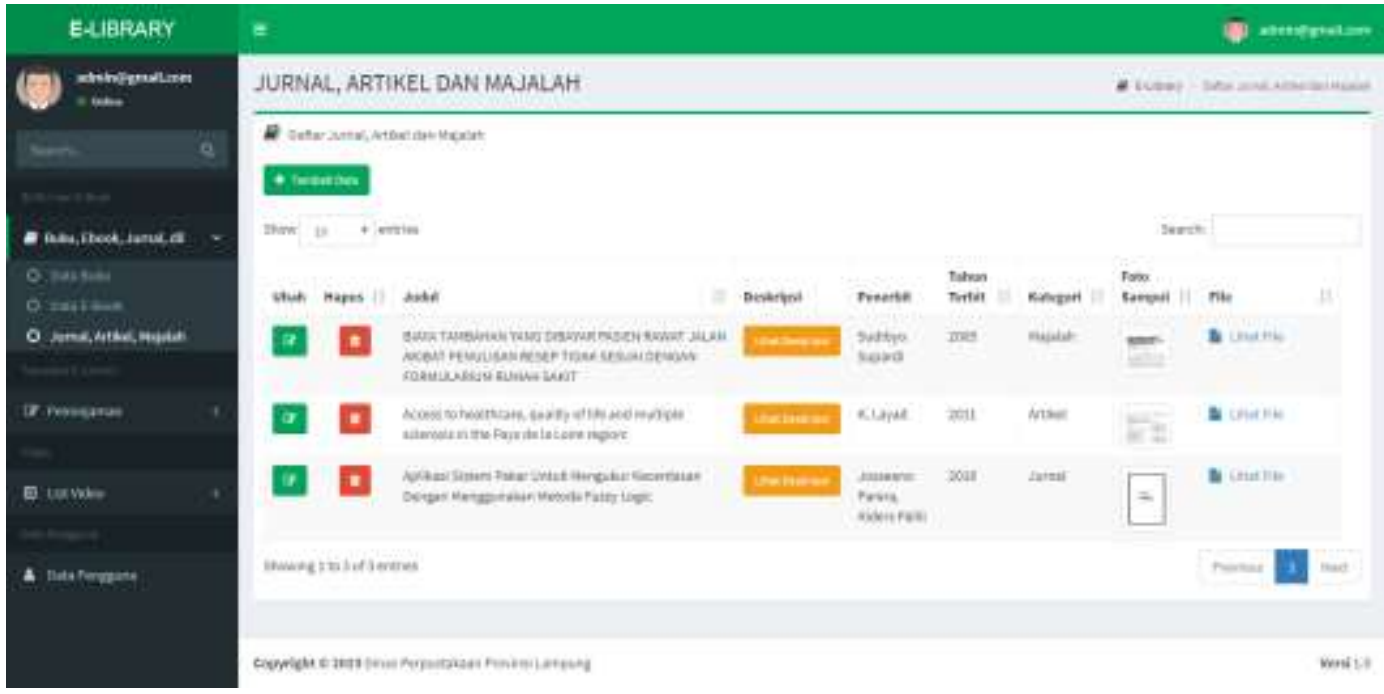

Gambar 7. Tampilan Data Jurnal

h. Tampilan Peminjaman

Menampilkan data Peminjam yang ada dan berfungsi untuk mengkonfirmasi data pinjaman.

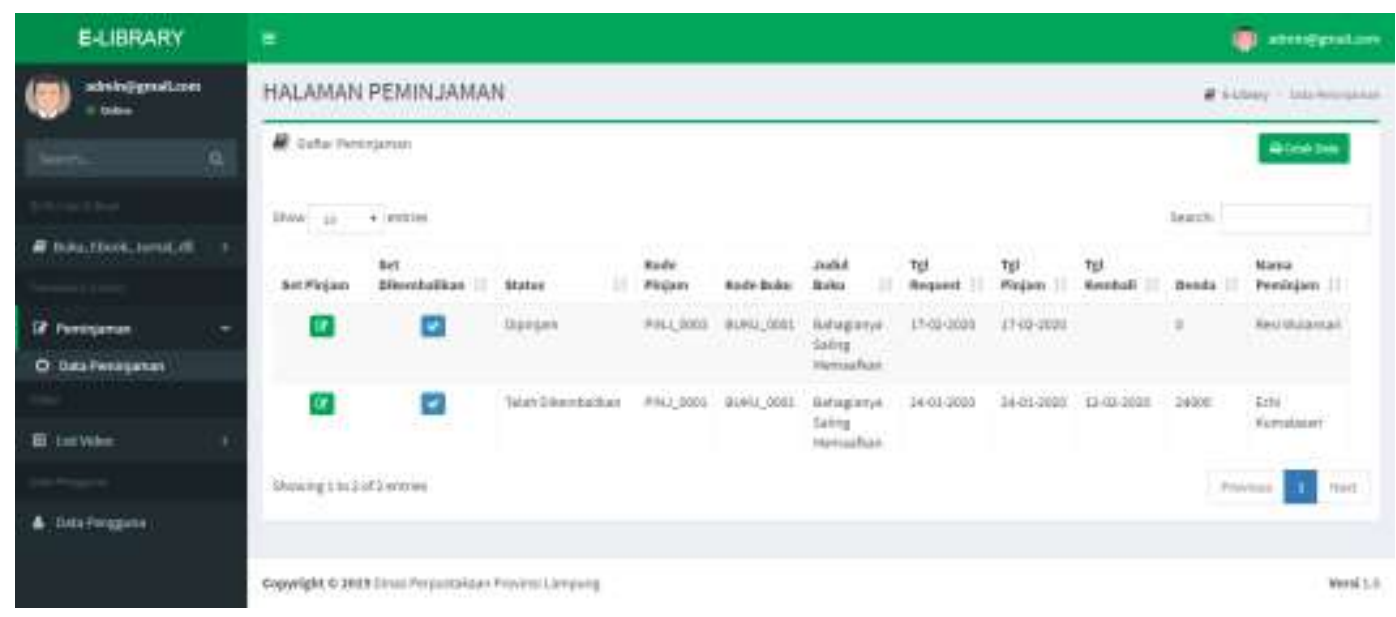

Gambar 8. Tampilan Data Peminjman

\section{KESIMPULAN}

Berdasarkan latar belakang dan pembahasan bab-bab sebelumnya maka dapat disimpulkan bahwa :

1. Dengan adanya sistem perpustakaan digital ini, maka dapat memudahkan masyarakat dalam pencarian informasi berupa buku, e-book, maupun konten digital lainnya pada Dinas Perpustakaan dan Kearsipan Provinsi Lampung.

2. Dengan adanya sistem perpustakaan digital ini, maka dapat meningkatkan minat baca dan budaya literasi di Provinsi Lampung.

Adapun saran yang diajukan untuk penelitian yang akan datang adalah : 
1. Perlu meningkatkan keamanan sistem dengan menggunakan Captcha agar terhindar dari spam.

2. Pembuatan Website ini masih sangat sederhana, terutama dari segi penampilan dan segi keamanan, sehingga ada baiknya di pengembangan sistem selanjutnya dapat membuat website ini menjadi lebih menarik dan sistem keamanannya lebih terjamin.

\section{DAFTAR PUSTAKA}

A.S., Rosa dan Shalahuddin, M.2019. Rekayasa Perangkat Lunak Terstruktur dan Berorientasi Objek. Bandung: Informatika Bandung.

Andoyadi, Hanum Latifa, Nur Atiqa. 2016. Proses Pengolahan Bahan Pustaka di Perpustakaan MAN 2 Pontianak. Pendidikan dan Pembelajaran Khatulistiwa. MAN 2, Pontianak.

Asmara, Rini. 2016. Perancangan Sistem InformasiPenyewaan Peralatan Pernikahan berbasis Android ( Studi Kasus: UD Manalagi Kabupaten Toraja Utara). Paulus Informatic Journal. Toraja Utara.

Firman, Astaria dan Wowor, F Hans \& Najoan, Xaverius. 2016. Sistem Informasi Perpustakaan Online Berbasis web. Teknik Elektro dan Komputer. Universitas Sam Ratulangi, Manado.

Oktafiani, Dwi. 2017. Perancangan Sistem Informasi Jurnal Online Pada Politeknik Anika Palembang Berbasis Web Mobile. Teknologi Informasi. Universitas Bina Insan, Palembang.

Nurrohmah, Siti dan Idris, Muhammad. 2019. Analisis Pengembangan E-Library SMK Ma'arif Banyumas sebagai Media Tatakelola Perpustakaan. Pendidikan Al-Multazam. SMK Ma'arif, Banyumas.

Sahara, Fitriani dan Andriana, Rena. 2016. Aplikasi E-Katalog Perpustakaan Berbasis Mobile Android. Manajemen Informatika Universitas Global Mandiri. Palembang.

Pressman, R.S. 2010. Rekayasa Perangkat Lunak : Pendekatan Partisi Buku 1. Yogyakarta:Andi. 